\title{
Nerve and muscle microvasculitis in peripheral neuropathy: a remote effect of cancer?
}

\author{
D VINCENT,* F DUBAS,* JJ HAUW,$^{*}$ P GODEAU, $\dagger$ F LHERMITTE, $\ddagger$ A BUGE,§ \\ P CASTAIGNE \|
}

From Laboratoire de Neuropathologie Charles Foix, ${ }^{*}$ Service de Médecine Interne, $\dagger$ Clinique de Neurologie et de Neuropsychologie, $\ddagger$ Clinique Neurologique§ and Clinique des Maladies du Système Nerveux, || Groupe Hospitalier Pitié-Salpétrière, Paris, France

SUMMARY In a series of 50 cases in which nerve and/or muscle microvasculitis was seen on biopsy, seven were associated with malignancy. In two cases, the cancer was found after the discovery of microvasculitis. All patients exhibited sensory-motor neuropathy, which was often painful and asymmetrical, with a progressive course. ESR and CSF protein levels were always elevated. Motor conduction velocity was slightly reduced in three cases, unmeasurable in one case, and normal in three. Cancers involved were adenocarcinoma in five cases (three prostate and two lung), Hodgkin's disease in one and immunoblastic lymphadenopathy in one. A thorough search for cancer should be performed when microvasculitis is seen in nerve or muscle biopsy specimens, especially when ESR and CSF protein levels are elevated.

Reports of nerve and/or muscle vasculitis in peripheral neuropathy associated with cancer are scarce. ${ }^{1-5}$ Seven cases of nerve and/or muscle microvasculitis shown by biopsy were studied in patients with cancer. These observations came from a series of 50 cases of microvasculitis, selected from among 1076 biopsy specimens at the Laboratoire de Neuropathologie Charles Foix in La Salpétrière Hospital during a 5-year period (1977-1982). The clinical files of all 50 cases were reviewed in 1983, and the aetiology of the microvasculitis was assessed in each case after a postbiopsy follow-up of one to five years. ${ }^{6}$

\section{Patients and methods}

\section{Patients}

Case 1: A 54-year-old woman who smoked cigarettes, previously in good health, presented with a very painful sensory motor multiple mononeuropathy of a few weeks duration, involving both lower limbs, that was more pronounced on the left side. Polyarthralgia and weight loss were associated. Erythema nodosum of lower limbs was noted on admission.

Address for reprint requests: Dr JJ Hauw, Laboratoire de Neuropathologie Charles Foix, Hôpital de la Salpétrière, 47, boulevard de l'Hôpital, 75651 Paris Cedex 13, France.

Received 2 July 1985 and in revised form 20 November 1985. Accepted 23 November 1985.
A skin biopsy specimen showed microvasculitis of the dermis. Routine tests revealed hypereosinophilia $\left(800 / \mathrm{mm}^{3}\right)$ and hyponatraemia, related to an inappropriate secretion of antidiuretic hormone. Fiberoptic bronchoscopy showed lung adenocarcinoma, which was subsequently excised. Adjuvant chemotherapy included prednisone, vindesin and cisplatinium. The motor signs improved over 9 months, and then the neuropathy relapsed. The patient was lost to follow up 11 months after the onset of the neuropathy. Biopsy was performed 1.5 months after the beginning of the neuropathy and 2 months before the discovery of the malignancy.

Case 2: A 65-year-old man who smoked cigarettes, previously in good health, was operated on for lung adenocarcinoma. One month later, he developed lower limb pain, then weakness of all four limbs, with diffuse wasting and absent tendon reflexes. There was decreased sensation of all modalities in distal lower limbs. Symptoms and signs worsened until death due to acute pulmonary failure, 3 months after the onset of the neuropathy. Biopsy was performed 2 months after the beginning of the neuropathy and 3 months after the discovery of the malignancy.

Case 3: A 78-year-old man, with no previous pertinent medical history, presented with progressive symmetrical pain, numbness and weakness of the lower limbs of one year's duration. On examination, there was weakness of distal muscles of four limbs, absence of deep tendon reflexes and decreased position sense of the lower limbs. In addition, there was dysphagia, loss of weight, and generalised pruritus. Routine tests disclosed marked eosinophilia $\left(1100 / \mathrm{mm}^{3}\right)$. Electrophysiological studies revealed a Lambert-Eaton syndrome. Thorough search for cancer, 


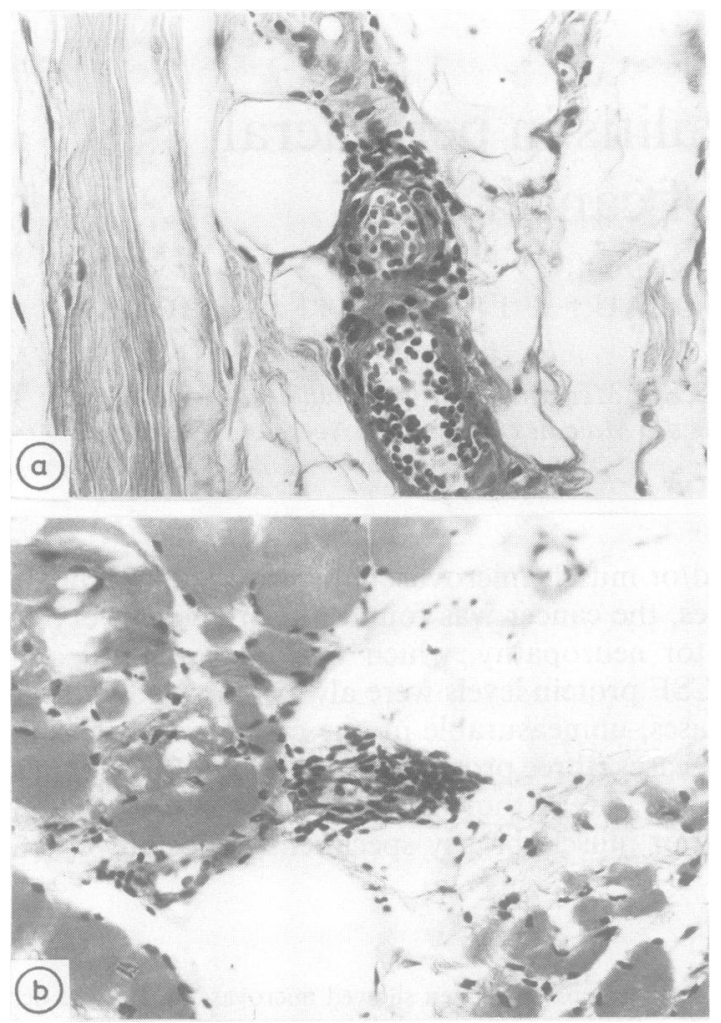

Fig (a) Nerve biopsy. Infiltration of small epineural vessels by a few mononuclear cells. Case no 3. (prostate adenocarcinoma). (Haematoxylin and eosin $\times 310$.)

Fig (b) Muscle biopsy. Focal involvement of a small epimysial artery wall by a monocytic infiltrate. Case no 4. (prostate adenocarcinoma). (Haematoxylin and eosin $\times 125$.)

including chest radiography, fiberoptic bronchoscopy, bone marrow aspiration, intravenous pyelography, radioactive bone scan, acid phosphatase and abdominal CT scan was negative. Treatment by guanethidine was ineffective. The patient was then discharged. Twenty-nine months after the beginning of the neuropathy, prostate carcinoma was discovered. The patient was then lost to follow up. Biopsy was performed 14 months after the beginning of the neuropathy and 29 months before the discovery of the malignancy.

Case 4: A 73-year-old man had been treated for 5 months for prostate adenocarcinoma by radiotherapy and diethylstilboestrol, $2 \mathrm{mg}$ daily, when he developed proximal pain and weakness of lower limbs with loss of weight, becoming bedridden 6 months later. Examination showed diffuse wasting, weakness of lower limbs and left ulnar paresis. Deep tendon reflexes were absent in lower limbs. There was decreased sensation of all modalities in the lower extremities and in the left ulnar territory. Bone radiographs, radioactive bone scan and myelography were normal. The patient then was lost to follow up. Biopsy was performed 7 months after the beginning of the neuropathy, and 11 months after the discovery of the malignancy.

Case 5: A 78-year-old alcoholic man had been treated for 1 year for prostate adenocarcinoma by diethylstilboestrol, 3 mg daily. He developed distal tingling followed by diffuse progressive weakness of all four limbs. The patient was bedridden 3 months later. Examination showed absence of tendon reflexes and decreased sensation of all modalities in the distal upper and lower limbs. The patient died suddenly two weeks later. There was no post-mortem study. Biopsy was performed 3 months after the beginning of the neuropathy, and 13 months after the discovery of the malignancy.

Case 6: A 59-year-old man had a history of non insulindependent diabetes mellitus. Hodgkin's disease (type 2, stage III $\mathrm{Bb})$ was diagnosed. Before any treatment, one month after the clinical onset of the disease, bilateral foot drop and weakness of the left quadriceps appeared. Treatment included radiotherapy and chemotherapy (vincristine, melphalan, procarbazine and prednisone). Two months later, there was diffuse weakness of four limbs, with wasting and absent tendon reflexes. There was decreased sensation of all modalities in the distal four limbs. There was progressive regression of neurological signs and symptoms after treatment. Examination was normal 18 months after the onset of the neuropathy. Biopsy was performed 2 months after the discovery of Hodgkin's disease and one month after the onset of the neuropathy.

Case 7: Immunoblastic lymphadenopathy was diagnosed in a 72-year-old man with no pertinent medical history. Treatment included vincristine, cyclophosphamide, procarbazine and prednisone for 10 months. Two years later, bilateral proximal weakness of the lower limbs appeared, more pronounced on the left side, with bilateral pain in the anterior aspect of the thigh. Myelography was normal. No abnormal cells were found in the CSF. The weakness spontaneously resolved in 2 months. Four months later, bilateral foot drop with pain in both lower limbs appeared over a period of 2 weeks. On examination, there was marked symmetrical weakness of lower limbs and distal weakness of upper limbs. A new lymph node biopsy confirmed the diagnosis of immunoblastic lymphadenopathy. Corticoid therapy was followed by transient improvement of the neuropathy. The patient died one month later, from septicaemia with meningitis and disseminated intravascular coagulation. Postmortem examination did not disclose any malignant infiltration in lymph nodes, liver, spleen, brain, spinal cord and peripheral nerves (lumbar plexus, brachial plexus and peroneal nerves). Numerous pictures of microvasculitis were found in peripheral nerves. No encephalitis was seen.

\section{Methods}

Open nerve and muscle biopsies (superficial peroneal nerve and peroneus brevis) were performed for diagnostic purposes in our laboratory. A part of the specimen was fixed in formalin, embedded in paraffin, and cut in semi-serial sections (5 to 7 levels). These were stained with haematoxylineosin, PAS, MASSON's trichrome and, sometimes MayGrünwald-Giemsa stain. Cases were selected on the basis of presence of microvasculitis, that is inflammatory cell infiltration surrounding and invading vessel walls, with involvement of small-sized vessels and sparing of arteries 
Table 1 Nerve and muscle microvasculitis in cancer. General data

\begin{tabular}{|c|c|c|c|c|c|c|c|}
\hline $\begin{array}{l}\text { Patient } \\
\text { (case) } \\
\text { No }\end{array}$ & $\operatorname{Sex}$ & $\begin{array}{l}\text { Age } \\
(y r)\end{array}$ & $\begin{array}{l}\text { Site of } \\
\text { microvasculitis }\end{array}$ & $\begin{array}{l}\text { Type of malignant } \\
\text { disease }\end{array}$ & $\begin{array}{l}\text { Interval between } \\
\text { symptoms of } \\
\text { malignant disease } \\
\text { and discovery of } \\
\text { neuropathy } \\
\text { (months) }\end{array}$ & $\begin{array}{l}\text { Interval between } \\
\text { symptoms of } \\
\text { neuropathy and } \\
\text { discovery of } \\
\text { malignant disease } \\
\text { (months) }\end{array}$ & $\begin{array}{l}\text { Associated } \\
\text { disorders }\end{array}$ \\
\hline $1(8257)$ & $\mathbf{F}$ & 54 & Muscle & Lung adenocarcinoma & & 3 & $\begin{array}{l}\text { Inappropriate } \\
\text { secretion of } \\
\text { antidiuretic } \\
\text { hormone }\end{array}$ \\
\hline $\begin{array}{l}2(6834) \\
3(6470)\end{array}$ & $\begin{array}{l}\mathbf{M} \\
\mathbf{M}\end{array}$ & $\begin{array}{l}65 \\
78\end{array}$ & $\begin{array}{l}\text { Muscle + nerve } \\
\text { Muscle + nerve }\end{array}$ & $\begin{array}{l}\text { Lung adenocarcinoma } \\
\text { Prostate } \\
\text { adenocarcinoma }\end{array}$ & 1 & 29 & $\begin{array}{l}\text { Lambert-Eaton } \\
\text { syndrome }\end{array}$ \\
\hline $4(7486)$ & $\mathbf{M}$ & 73 & Muscle & $\begin{array}{l}\text { Prostate } \\
\text { adenocarcinoma }\end{array}$ & 5 & & $\begin{array}{l}\text { Diabetes } \\
\text { mellitus }\end{array}$ \\
\hline $5(7234)$ & $\mathbf{M}$ & 78 & Muscle & $\begin{array}{l}\text { Prostate } \\
\text { adenocarcinoma }\end{array}$ & 8 & & \\
\hline $6(6982)$ & $\mathbf{M}$ & 59 & Muscle + nerve & Hodgkin's disease & 1 & & $\begin{array}{l}\text { Diabetes } \\
\text { mellitus }\end{array}$ \\
\hline $7(7020)$ & $\mathbf{M}$ & 72 & Nerve & $\begin{array}{l}\text { Immunoblastic } \\
\text { lymphadenopathy }\end{array}$ & 23 & & \\
\hline
\end{tabular}

Table 2 Nerve and muscle microvasculitis in cancer. Laboratory data

\begin{tabular}{|c|c|c|c|c|}
\hline \multirow[t]{2}{*}{ Case No } & \multirow{2}{*}{$\begin{array}{l}\text { Erythrocyte sedimentation } \\
\text { rate }(\mathrm{mm})\end{array}$} & \multicolumn{3}{|c|}{ Cerebrospinal fluid analyses } \\
\hline & & Cells per $\mathrm{mm}^{3}$ & Protein $\mathrm{g} / \mathrm{l}$ & Percentage of gamma-globulin \\
\hline $\begin{array}{l}1 \\
2 \\
3 \\
4 \\
5 \\
6 \\
7\end{array}$ & $\begin{array}{l}58 \\
38 \\
12 \\
25 \\
68 \\
90 \\
40\end{array}$ & $\begin{array}{l}4 \cdot 2 \\
0 \cdot 4 \\
1 \\
2 \\
0 \cdot 2 \\
0 \cdot 8 \\
0 \cdot 8\end{array}$ & $\begin{array}{l}1.55 \\
1.21 \\
0.74 \\
0.81 \\
0.47 \\
0.95 \\
0.64\end{array}$ & $\begin{array}{r}17 \\
23 \\
3 \\
6 \\
5 \\
15 \\
8\end{array}$ \\
\hline
\end{tabular}

larger than $70 \mu \mathrm{m}$ in diameter. In muscle samples, only perimysial microvasculitis was considered. In addition, all patients had cancer proven by biopsy, as detailed in table 1 . No other cause of microvasculitis was present (collagen disease, infection or drug).

\section{Results}

Microvasculitis The changes were observed in both nerve and muscle biopsies in four cases, in muscle alone in two cases, and in nerve alone in one case (table 1). Although it was sometimes difficult to assess in different sections whether different vessels were involved, there were always two or more sites of vasculitis in nerve and muscle samples. In most cases it consisted of pure mononuclear cell infiltration. In two cases (nos 3 and 6), a few polymorphonuclear cells were seen in the largely predominant mononuclear cell infiltrate. No leucocytoclasis or fibrinoid necrosis were observed. No malignant cells were seen. In the muscle biopsy specimens, denervation atrophy was observed in every case. In addition, the presence of necrotic and basophilic fibres was noted in cases 4 and 6. Nerve biopsies exhibited non-specific changes indicative of axonal degeneration in all cases except for case 7 . In no case was the diagnosis of polymyositis made.

Patient profile The patients most frequently exhibited a progressive (cases $2,3,4,5$ ), asymmetrical (cases 1, 3, 4, 6), painful (cases 1, 2, 3, 4) neuropathy of the sensorimotor type. A major proximal motor deficit was seen in cases 2, 4 and 7. Conspicuous improvement with subsequent relapse was seen either spontaneously (case 7) or after chemotherapy (cases 1 and 6). Bulbar palsy was present in two patients (cases 3 and 5). With the exception of one case in which erythema nodosum was observed (1), there were no signs of systemic vasculitis. No signs or symptoms of central nervous system involvement were noted. CSF and erythrocyte sedimentation rate (ESR) data are given in table 2. CSF protein levels and ESR were always elevated. Electrophysiological data are given in table 3. Motor conduction velocities were normal or slightly reduced. Sensory nerve action 
Table 3 Electrophysiological investigations

\begin{tabular}{|c|c|c|c|c|c|}
\hline \multirow{2}{*}{$\begin{array}{l}\text { Case } \\
\text { No }\end{array}$} & \multicolumn{3}{|c|}{$M C V(\mathrm{~m} / \mathrm{s}) / D L(\mathrm{~ms})$} & \multicolumn{2}{|c|}{$S C V(m / s) / A m p l(\mu V)$} \\
\hline & Median $n$. & Ulnar $n$ & Peroneal $n$. & $\begin{array}{l}\text { Median n. } \\
\text { (dig. I-wrist) }\end{array}$ & Sural $n$. \\
\hline $\begin{array}{l}1 \\
2 \\
3 \\
4 \\
5 \\
5 \\
6 \\
7\end{array}$ & $\begin{array}{l}\text { R: } 58 \cdot 4 \\
\bar{R}: 44 \cdot 2 / 5 \\
\text { R: } 46 \cdot 6 / 5 \cdot 7 \\
\overline{-} \\
\text { R: } 45 \cdot 7 / 3 \cdot 8 \\
\text { L: } 39 \cdot 4 / 3 \cdot 5\end{array}$ & $\begin{array}{l}\text { R: } 60 \\
\text { R: } 43 \cdot 6 / 4 \cdot 1 \\
\text { R: } 48 / 3 \cdot 2 \\
\text { L: } 41 \cdot 6 / 3 \cdot 5 \\
\text { Non-measurable } \\
- \\
-\end{array}$ & $\begin{array}{l}47 \cdot 6 \\
\text { R: } 31 \cdot 1 / 11 \cdot 7 \\
\text { Non-measurable } \\
\text { Non-measurable } \\
\text { Non-measurable } \\
\text { L: } 35 \\
\text { R: } 22 \cdot 8 / 5 \cdot 1\end{array}$ & $\begin{array}{l}- \\
\bar{Z} \\
39 \cdot 2 / 4 \\
\text { Non-measurable } \\
\overline{\text { R: }} 32 \cdot 3 / 5 \\
\text { L: non-measurable }\end{array}$ & $\begin{array}{l}- \\
\overline{-} \\
\text { Non-measurable } \\
\text { Non-measurable } \\
- \\
-\end{array}$ \\
\hline
\end{tabular}

MCV: motor conduction velocity. DL: distal latency. SCV: sensory conduction velocity. Ampl: amplitude of the sensory nerve action potential. R: right. L: left.

potentials were altered in three cases. Lambert-Eaton syndrome was present in case 3 .

\section{Discussion}

Cancer-related microvasculitis has often been suggested, ${ }^{7}$ mainly involving the skin. ${ }^{8}$ A few reports have suggested that the presence of microvasculitis in peripheral neuropathies could be a remote effect of cancer. ${ }^{2-5}$ In our series, there was one case of Hodgkin's disease and one of immunoblastic lymphadenopathy. Other associated conditions were adenocarcinomas: two involving the lung, and three the prostate. No prostate carcinoma has yet been reported in peripheral neuropathy with microvasculitis, though the association of this site of malignancy and neuropathy have already been mentioned in the literature. ${ }^{910}$ In one of our cases (case 3), a Lambert-Eaton syndrome was associated with microvasculitis and prostatic carcinoma. This association has been only rarely noted. ${ }^{11}$ Although no postmortem study was performed, the 29-month interval between the discovery of the peripheral neuropathy and that of the cancer rendered the coexistence of another malignant disease unlikely. In conclusion, a thorough search for cancer should be performed when microvasculitis is seen in nerve or muscle biopsy, especially when ESR and CSF protein levels are elevated.

We thank Drs P Bouche, HP Cathala and J Scherrer for the nerve conduction velocity studies, Dr E Schuller for CSF analysis, Dr H Baron and M Smith for the English translation and Mrs Bethermin, Freytag, Fenoy and Mr P Miele for technical help.

\section{References}

${ }^{1}$ Bekeny G. Uber das neuromyositis-syndrom. Dtsch Z Nervenheilk 1968;193:324-50.

2 Boudin G, Pépin B, Brion S, Labet R, Lauras A, Lyon G. Affections malignes et neuropathies dégénératives. Presse Med 1962;70:675-8.

${ }^{3}$ Brunet P, Binet JL, de Saxce $\mathrm{H}$, et al. Neuropathies au cours de la lymphadénopathie angioimmunoblastique. Rev Neurol (Paris) 1981;137:503-15.

${ }^{4}$ Croft PB, Urich H, Wilkinson M. Peripheral neuropathy of sensorimotor type associated with malignant disease. Brain 1967;90:31-66.

5 Johnson PC, Rolak LA, Hamilton RH, Laguna JF. Paraneoplastic vasculitis of nerve: a remote effect of cancer. Ann Neurol 1979;5:437-44.

${ }^{6}$ Vincent D, Dubas F, Hauw JJ, et al. Microvasculites nerveuses et musculaires: 50 cas. Rev Neurol (Paris) 1985;141:440-6.

${ }^{7}$ Cupps TR, Fauci AS. The Vasculitides. Philadelphia: Saunders, 1981:116-22.

${ }^{8}$ McCombs RP. Systemic "allergic" vasculitis, clinical and pathological relationship. JAMA 1965;194:1059-64.

${ }^{9}$ Escourolle R, Sznajder L. Corrélations anatomiques, électromyographiques et cliniques, à propos de 200 biopsies de muscles des ceintures. In: Serratrice G, ed. Les Atteintes des Muscles des Ceintures chez l'Adulte. Paris: Expansion Scientifique, 1969:51-60.

${ }^{10}$ McLeod JG. Carcinomatous neuropathy. In: Dyck PJ, Thomas PK, Lambert EH, eds. Peripheral neuropathy. Philadelphia: Saunders, 1984:2180-91.

${ }^{11}$ Henson RA, Urich H. Cancer and the Nervous System. Oxford: Blackwell Scientific Publications, 1982. 